\title{
Effect of transcription on folding of the Tetrahymena ribozyme
}

\author{
SUSAN L. HEILMAN-MILLER ${ }^{1,3}$ and SARAH A. WOODSON ${ }^{2}$ \\ ${ }^{1}$ Department of Chemistry and Biochemistry, University of Maryland, College Park, Maryland 20742-2021, USA \\ ${ }^{2}$ T.C. Jenkins Department of Biophysics, Johns Hopkins University, Baltimore, Maryland 21218-2865, USA
}

\begin{abstract}
Sequential formation of RNA interactions during transcription can bias the folding pathway and ultimately determine the functional state of a transcript. The kinetics of cotranscriptional folding of the Tetrahymena L-21 ribozyme was compared with refolding of full-length transcripts under the same conditions. Sequential folding after transcription by phage T7 or Escherichia coli polymerase is only twice as fast as refolding, and the yield of native RNA is the same. By contrast, a greater fraction of circularly permuted variants folded correctly at early times during transcription than during refolding. Hybridization of complementary oligonucleotides suggests that cotranscriptional folding enables a permuted RNA beginning at G303 to escape nonnative interactions in P3 and P9. We propose that base pairing of upstream sequences during transcription elongation favors branched secondary structures that increase the probability of forming the native ribozyme structure.
\end{abstract}

Keywords: RNA structure; sequential folding; in vitro transcription; native gel electrophoresis; group I intron; E. coli RNA polymerase; T7 RNA polymerase

\section{INTRODUCTION}

The assembly of large RNA structures is a complex process, because the RNA can make a large number of native and non-native interactions (Woodson 2000). $\mathrm{Mg}^{2+}$-dependent folding of the Tetrahymena group I ribozyme is slow due to partially misfolded intermediates that persist for long times (Zarrinkar and Williamson 1994; Pan et al. 1997; Pan and Woodson 1998). A comparison of self-splicing rates, however, suggests that the ribozyme reaches its active conformation 20-fold faster in vivo than in vitro (Brehm and Cech 1983; Zhang et al. 1995).

One difference is that RNAs begin to fold as they are transcribed in the cell (Fig. 1). Consequently, secondary and tertiary interactions can form within the $5^{\prime}$ end of the RNA before the $3^{\prime}$ end of the chain is synthesized (Boyle et al. 1980; Kramer and Mills 1981). This has several implications for the assembly of RNA structure. First, sequential folding

Reprint requests to: Sarah A. Woodson, T.C. Jenkins Department of Biophysics, Jenkins Hall, Johns Hopkins University, 3400 N. Charles St., Baltimore, MD 21218-2865, USA; e-mail: swoodson@jhu.edu; fax: (410) 516-4118.

Present address: ${ }^{3}$ Laboratory of Molecular Genetics, National Institute of Child Health and Human Development, 9000 Rockville Pike, Bethesda, MD 20892, USA.

Article and publication are at http://www.rnajournal.org/cgi/doi/ 10.1261/rna.5200903. during transcription is expected to favor local structure over long-range interactions that require synthesis of the entire RNA chain. Hence, folding intermediates formed during transcription may differ from those formed during refolding of full-length RNA.

Second, intermediate structures formed during transcription are not static. Comparison of RNA fragments of increasing length from chain termination reactions (Kramer and Mills 1981), or direct observation of RNA conformers on acrylamide gels (Repsilber et al. 1999), found that interactions formed early during transcription can be displaced later by more thermodynamically stable interactions. The stability of the folding intermediates determines the time required to rearrange to the final structure, and hence the overall folding time.

Third, the rate of RNA elongation and the extent of pausing may alter the distribution of folding intermediates by limiting the conversion of one structure to another. For example, decreasing the rate of $\mathrm{T} 7$ transcription by lowering nucleotide triphosphate concentrations was reported to increase the number of metastable folding intermediates formed during transcription of the potato spindle tuber viroid RNA (Repsilber et al. 1999). Rapid elongation by phage polymerases leads to inactive transcripts of col E1 RNA II and ribosomal RNA (Lewicki et al. 1993; Chao et al. 1995). 


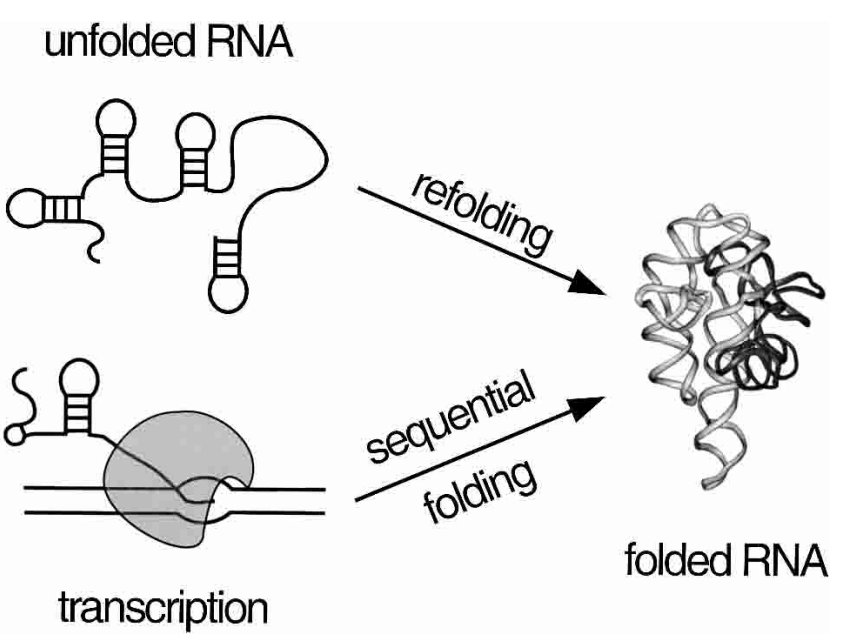

FIGURE 1. Folding during transcription versus refolding. Typical folding experiments are conducted with full-length RNA (refolding). Secondary and tertiary interactions initially formed as the RNA exits the transcription elongation complex (sequential folding) may be different than those formed during refolding, and may persist after transcription is complete.

Importantly, kinetically trapped intermediates can create a time window for gene regulation. For example, refolding of a metastable structure regulates translation in Escherichia coli phage MS2 (Groeneveld et al. 1995; Poot et al. 1997) and the activity of antisense RNAs expressed by plasmidborne killer genes (Nagel et al. 1999). In bacterial prerRNA, a metastable interaction with leader sequences promotes proper assembly of $30 \mathrm{~S}$ ribosome and maturation of the 16 S rRNA (Balzer and Wagner 1998; Besancon and Wagner 1999).

Catalytic RNAs can be used to study the coupling between transcription and RNA folding, because the RNA can also be refolded in vitro. The RNA component of Bacillus subtilis RNase $\mathrm{P}$ folds by a different pathway during transcription than during $\mathrm{Mg}^{2+}$-induced refolding (Pan et al. 1999a). Overall, cotranscriptional folding is only twice as fast as refolding, because intermediate conformations appear during transcription, which rearrange slowly to the native conformation (Pan et al. 1999a). Addition of the elongation factor NusA to transcription reactions, however, improved folding of a circularly permuted form of RNase $\mathrm{P}$ 10-fold (Pan et al. 1999a). Presumably, increased pausing of the transcription elongation complex in the presence of NusA allows more time for structural rearrangements in the RNA before additional sequences are transcribed (Pan et al. 1999a).

To examine the possibility that transcription alters folding pathways of the Tetrahymena ribozyme, we examined the rate of folding immediately after RNA synthesis, using native gel electrophoresis. In general, a greater fraction of the RNA population forms active ribozyme when allowed to fold during transcription by either T7 or E. coli RNA polymerase. For the wild-type ribozyme, however, sequential folding was only twice as fast as refolding. By contrast, refolding and sequential folding of circularly permuted variants differed as much as 10 -fold. These results suggest that sequence context plays a strong role in the assembly of RNA structural domains during transcription.

\section{RESULTS}

\section{Cotranscriptional folding of the L-21 ribozyme}

Folding of the Tetrahymena L-21 Sca ribozyme was monitored by native gel electrophoresis (Emerick and Woodson 1994). After preincubation in $\mathrm{Mg}^{2+}$, native ribozyme migrates as a single band $(\mathrm{N})$ in the gel (Fig. 2A). If unrenatured, the majority of the RNA forms a broad smear of lower electrophoretic mobility, corresponding to multiple folding intermediates (I) that convert to the native structure over 20 min (Fig. 2A). A small amount $(2 \%-5 \%)$ of RNA folds during the time required to load samples into the

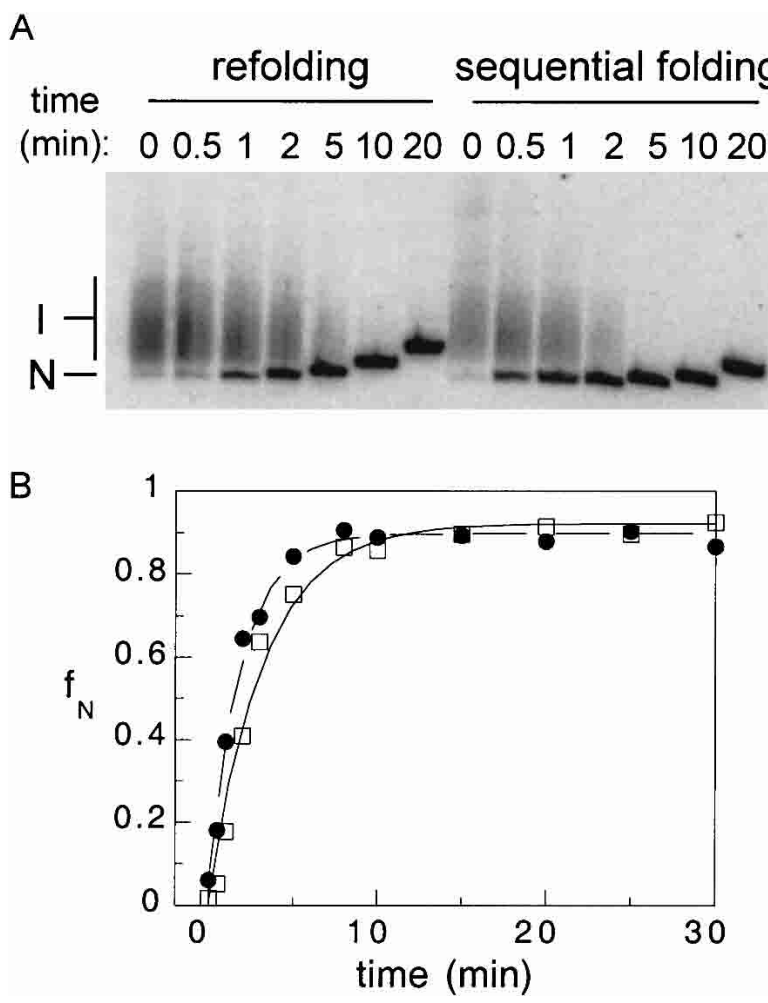

FIGURE 2. Transcription increases the folding kinetics of the Tetrahymena ribozyme. L-21 ribozyme RNA was incubated in T7 buffer ( 40 $\mathrm{mM}$ TrisCl, $\mathrm{pH} 7.5,15 \mathrm{mM} \mathrm{MgCl}_{2}, 5 \mathrm{mM}$ DTT, and $2 \mathrm{mM}$ spermidine), NTPs, and $10 \mu \mathrm{g} / \mu \mathrm{L}$ heparin at $37^{\circ} \mathrm{C}$ (refolding), or transcribed from template DNA under the same conditions (sequential folding). (A) At various times, samples were loaded directly on a native $8 \%$ polyacrylamide gel. Band I, folding intermediates; band $\mathrm{N}$, native RNA. The gel was run continuously during the assay so that samples loaded last traveled the shortest distance. $(B)$ Fraction native RNA determined from native gels $\left(f_{\mathrm{N}}\right)$ versus incubation time was fit to a first-order rate equation. Refolding (open squares) $k_{\mathrm{obs}}=0.31 \pm 0.2$ $\mathrm{min}^{-1}$; sequential folding (filled circles) $k_{\mathrm{obs}}=0.51 \pm 0.03 \mathrm{~min}^{-1}$. 
native gel (15-30 sec) (Pan et al. 2000). Hence, this method measures (1) the fraction of the RNA population that rapidly folds to the native state, and (2) the time required for reorganization of intermediate structures formed during transcription (Pan et al. 1997).

To compare sequential folding with refolding of the Tetrahymena ribozyme, transcription T7 RNA polymerase was preincubated with template DNA, and transcription begun with the addition of nucleotide triphosphates. Transcription was limited to a single round by the addition of heparin, which blocks reinitiation of the polymerase (Daube and von Hippel 1994). Samples were loaded directly onto a native polyacrylamide gel at various times after the start of transcription (Fig. 2A). As the rate of folding is extremely sensitive to counterion concentrations (Heilman-Miller et al. 2001), refolding reactions were carried out under identical conditions by adding full-length ribozyme to a mock T7 transcription reaction at $37^{\circ} \mathrm{C}$.

T7 transcription of the 385-nt ribozyme requires about 2 sec (Golomb and Chamberlin 1974), and the formation of local secondary structure about 10-100 $\mu \mathrm{sec}$ (Cole and Crothers 1972; LeCuyer and Crothers 1994; Ansari et al. 2001; Wallace et al. 2001). Thus, synthesis of the ribozyme and initial folding steps are complete within the shortest time of our assay. As intermediates formed during transcription may not have the same structure and stability as those formed during refolding, a comparison of sequential and refolding kinetics can reveal how transcription alters the folding pathway of the ribozyme. Under conditions for in vitro T7 transcription, sequential folding $\left(k_{\mathrm{obs}}=0.51\right.$ $\left.\min ^{-1}\right)$ was slightly faster than refolding $\left(k_{\text {obs }}=0.31 \mathrm{~min}^{-1}\right.$; Fig. 2B). This difference was reproducible among three to five independent trials, and suggested that the process of transcription increased correct folding of the ribozyme.

\section{Effect of polymerase elongation rates on RNA folding}

To examine the effect of transcription elongation rates on folding of the L-21 ribozyme, transcription reactions were conducted as before, but using E. coli RNA polymerase (Fig. $3 \mathrm{~A})$. The average elongation rate of phage T7 RNA polymerase is 200-400 nt sec ${ }^{-1}$ in vitro (Golomb and Chamberlin 1974), compared to 10-35 nt $\mathrm{sec}^{-1}$ for E. coli RNA polymerase in vitro (Chamberlin et al. 1979; Wang et al. 1998). Transcription with E. coli RNA polymerase results in twofold faster formation of native ribozyme than refolding under the same conditions $\left(0.65 \mathrm{~min}^{-1}\right.$ versus $0.29 \mathrm{~min}^{-1}$; Fig. 3B). These values are very similar to those obtained under T7 transcription conditions (Fig. 2B). Thus, folding during transcription by either T7 or E. coli RNA polymerase doubles the folding rate of the L-21 ribozyme. However, differences in the elongation rates and other properties of the phage and bacterial polymerases have little effect on the folding kinetics of this transcript.
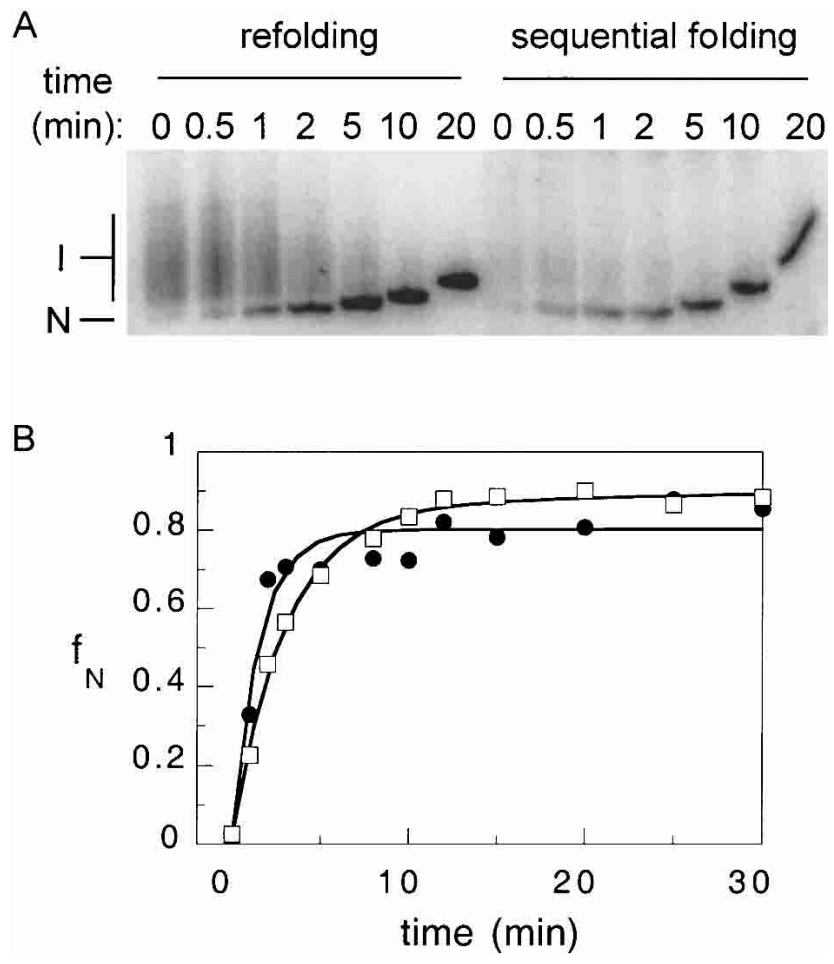

FIGURE 3. Effect of slower elongation rate of E. coli RNA polymerase on folding of Tetrahymena ribozyme. Ribozyme RNA was incubated in E. coli transcription buffer $(50 \mathrm{mM}$ TrisCl pH 7.8, $3 \mathrm{mM}$ magnesium acetate, $0.1 \mathrm{mM}$ EDTA, $0.1 \mathrm{mM}$ DTT, $250 \mu \mathrm{g} / \mu \mathrm{L}$ BSA), $0.96 \mathrm{mM}$ NTPS, and $1.2 \mathrm{mg} / \mathrm{mL}$ heparin at $37^{\circ} \mathrm{C}$ (refolding), or transcribed by E. coli RNA polymerase from added DNA template (sequential folding). (A) Native gel, as in Figure 2A. (B) Fraction native $\left(f_{\mathrm{N}}\right)$ versus time. Refolding (open squares), $k_{\text {obs }}=0.29 \pm 0.02 \mathrm{~min}^{-1}$; sequential folding (filled circles), $k_{\mathrm{obs}}=0.65 \pm 0.08 \mathrm{~min}^{-1}$.

\section{Effect of sequence order on sequential RNA folding}

To explore whether the order in which sequences are transcribed is important, folding experiments were conducted using circularly permuted (CP) variants of the Tetrahymena ribozyme (Fig. 4). We previously characterized nine permuted RNAs, whose 5' and 3' ends are relocated to different regions of the ribozyme (Heilman-Miller and Woodson 2003). The transcripts are designated by the position of the 5 ' end. The CP RNAs form the correct tertiary structure and retain catalytic activity when refolded in splicing buffer. The refolding kinetics vary 10 -fold among the permutants, however, demonstrating that the folding pathway is sensitive to the sequence distance between native interactions (Heilman-Miller and Woodson 2003). A CP RNA that begins near the natural $5^{\prime}$ end refolds at nearly the same rate as the L-21 ribozyme, while RNAs that begin in the P4-P6 domain refold more slowly.

Sequential folding of CP RNAs was compared with refolding under the conditions for T7 transcription, using native gel electrophoresis to quantify the fraction of native RNA (Fig. 4B). As for the L-21 ribozyme, formation of the native structure is improved when the CP RNAs are allowed 
A

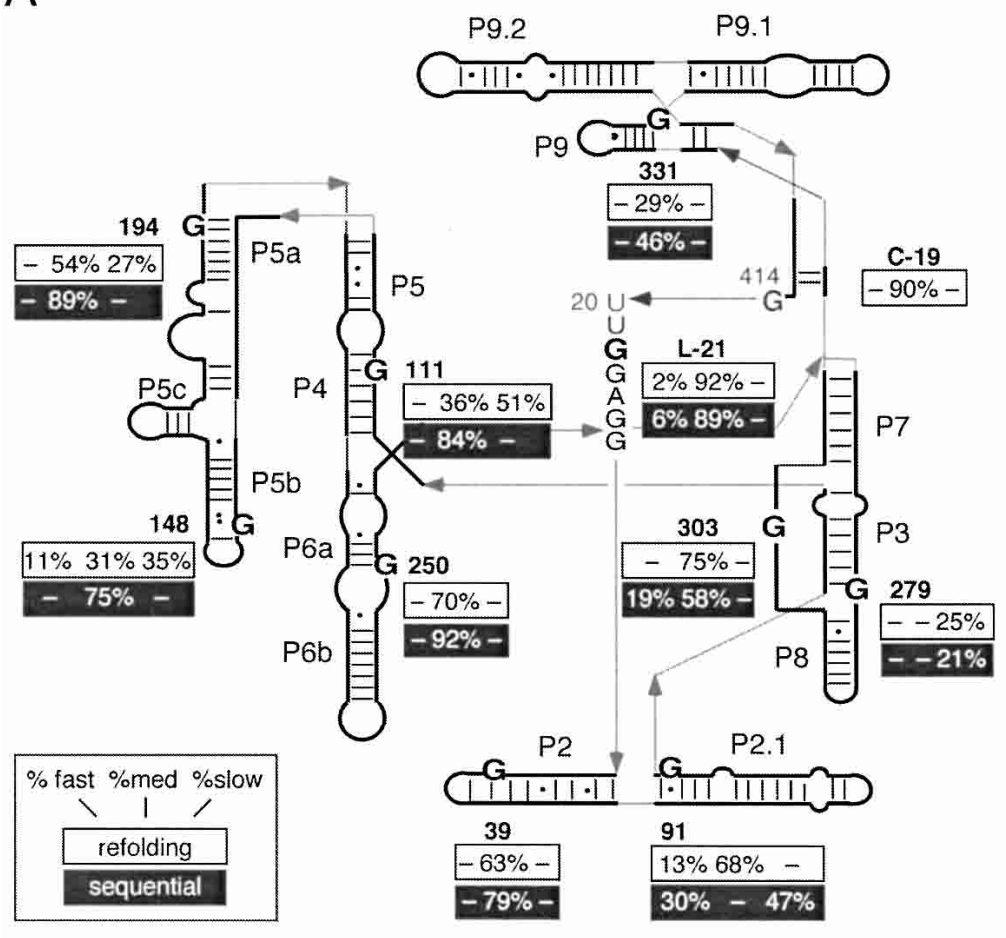

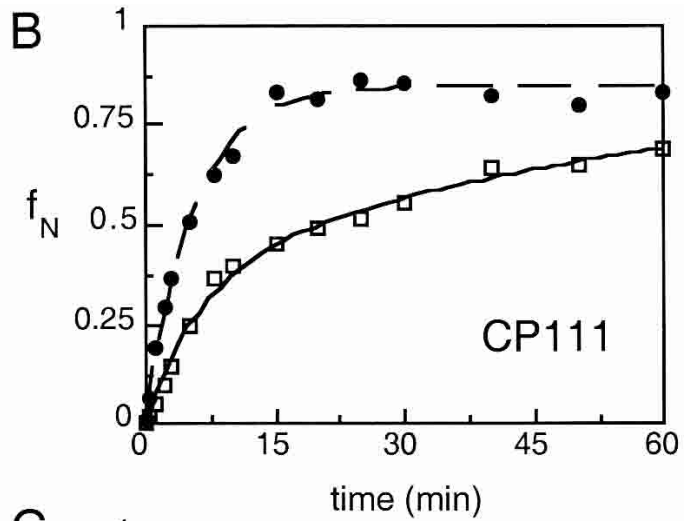

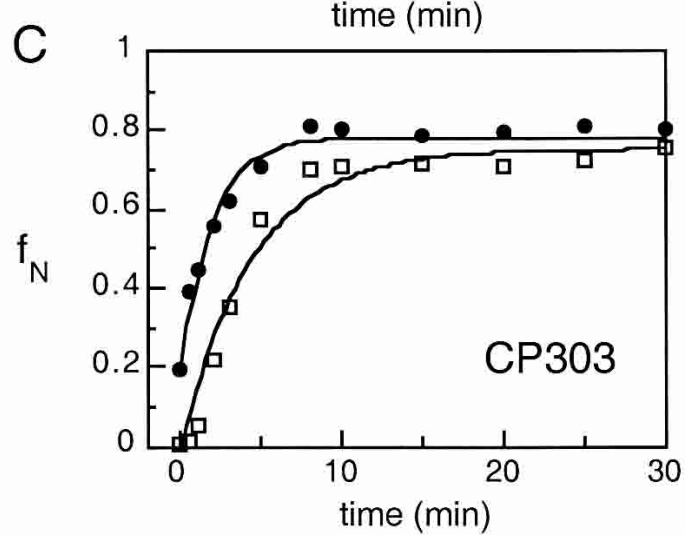

FIGURE 4. Effect of sequence order on sequential folding. (A) Diagram of circularly permuted (CP) variants of the Tetrahymena ribozyme (Heilman-Miller and Woodson 2003). Each CP is indicated by its $5^{\prime}$ end and terminates at the preceding nucleotide. Boxes show the fraction of RNA folding in fast $\left(\geq 1.3 \mathrm{~min}^{-1}\right)$, medium $\left(0.09\right.$ to $\left.0.55 \mathrm{~min}^{-1}\right)$, and slow $\left(0.01\right.$ to $\left.0.06 \mathrm{~min}^{-1}\right)$ phases. Folding reactions were performed at $37^{\circ} \mathrm{C}$ using T7 transcription conditions (Table 1). (B) CP111. Refolding (open squares) $\mathrm{A}_{1}=0.36, k_{1}=0.16 \pm 0.03 \mathrm{~min}^{-1}, \mathrm{~A}_{2}=0.51, k_{2}=0.017 \pm 0.006$ $\min ^{-1}$; sequential folding (filled circles) $\mathrm{A}_{1}=0.85, k_{1}=0.18 \pm 0.01 \mathrm{~min}^{-1}$. (C) CP303. Refolding (open squares) $\mathrm{A}_{1}=0.75, k_{1}=0.21 \pm 0.03 \mathrm{~min}^{-1}$; sequential folding (filled circles) $f_{\mathrm{N}}(0)=0.19, \mathrm{~A}_{1}=0.58, k_{1}=0.52 \pm 0.06 \mathrm{~min}^{-1}$.

to fold during T7 transcription, compared with refolding under the same conditions (Table 1). For CP39 (P2), CP250 (P6a), CP279 (P3), and CP331 (P9), the difference between sequential folding and refolding is similar in magnitude to the effect on the L-21 ribozyme (one to twofold rate enhancement; Table 1).

By contrast, transcription makes a large difference to the folding of CP111, CP148, and CP194, which begin in the P4-P6 domain (Table 1). These RNAs refold with biphasic kinetics in T7 transcription buffer (Fig. 4B), suggesting that the RNA population is partitioned among different metastable intermediates. The rate constants for the fast and slow kinetic phases are similar among the members of this group $\left(k_{1} \sim 0.16 \mathrm{~min}^{-1} ; k_{2} \sim 0.01 \mathrm{~min}^{-1}\right)$, but the proportion of the RNA refolding in the initial burst increases as the $5^{\prime}$ end of the transcript is moved further downstream.

Strikingly, the entire population $(75 \%-90 \%)$ of these CP RNAs folds at the faster rate constant $\left(k_{\text {fast }} \sim 0.16 \mathrm{~min}^{-1}\right)$ when allowed to fold sequentially during $\mathrm{T} 7$ transcription. This difference is most pronounced for CP111, of which $85 \%$ folds in the first $10 \mathrm{~min}$ after transcription, compared with $37 \%$ during refolding (Fig. 4B). Therefore, interactions formed during transcription increase the probability that these permuted RNAs will find the native conformation in a few minutes.

The refolding and sequential folding kinetics of the permuted RNAs were also compared under the conditions for E. coli transcription (Table 2). Overall, the sequential folding rates for each of the permuted RNAs were nearly the same (within error), whether the RNAs were transcribed by T7 or E. coli RNA polymerase. Thus, the elongation rate has only a small effect on folding, as we observed for the L-21 ribozyme. The rates of refolding, however, were greater for some CP RNAs under the conditions used for E. coli transcription reactions (Table 2), reducing the differences between sequential folding and refolding.

\section{Sequential folding of CP303 results in a fast folding phase}

Cotranscriptional folding also produces a population of CP91 and CP303 RNAs that fold within 15-30 sec (Fig. 4; Table 1), further evidence that sequential folding results in redistribution of the RNA population among competing pathways. Relocation of the $5^{\prime}$ end to position 303 in J8/7 has particularly interesting effects on the folding mecha- 
TABLE 1. Comparison of refolding and sequential folding rates, T7 RNA polymerase ${ }^{\mathrm{a}}$

\begin{tabular}{|c|c|c|c|c|c|c|c|c|c|c|}
\hline \multirow[b]{2}{*}{ RNA } & \multicolumn{5}{|c|}{ Refolding } & \multicolumn{5}{|c|}{ Sequential folding } \\
\hline & $f_{N}(0)$ & $A_{1}$ & $k_{1}\left(\min ^{-1}\right)$ & $\mathrm{A}_{2}$ & $k_{2}\left(\min ^{-1}\right)$ & $f_{\mathrm{N}}(0)$ & $A_{1}$ & $k_{1}\left(\min ^{-1}\right)$ & $\mathrm{A}_{2}$ & $k_{2}\left(\min ^{-1}\right)$ \\
\hline L-21 & 0.02 & 0.92 & $0.31 \pm 0.02$ & & & 0.06 & 0.89 & $0.51 \pm 0.03$ & & \\
\hline C-19 & 0.0005 & 0.90 & $0.09 \pm 0.005$ & & & $N A^{c}$ & $N A^{c}$ & $N A^{c}$ & & \\
\hline CP39 & 0.02 & 0.63 & $0.29 \pm 0.02$ & & & 0.02 & 0.79 & $0.31 \pm 0.02$ & & \\
\hline CP91 & 0.13 & 0.68 & $0.18 \pm 0.01$ & & & 0.1 & 0.20 & $1.34 \pm 0.3$ & 0.47 & $0.05 \pm 0.02$ \\
\hline CP111 & 0.006 & 0.36 & $0.16 \pm 0.03$ & 0.51 & $0.017 \pm 0.006$ & 0.01 & 0.84 & $0.18 \pm 0.01$ & & \\
\hline $\mathrm{CP} 148^{\mathrm{b}}$ & 0.11 & 0.31 & $0.20 \pm 0.04$ & 0.35 & $0.017 \pm 0.004$ & 0.005 & 0.75 & $0.18 \pm 0.01$ & & \\
\hline CP194 ${ }^{b}$ & 0.03 & 0.54 & $0.15 \pm 0.03$ & 0.27 & $0.01 \pm 0.008$ & 0.003 & 0.89 & $0.12 \pm 0.005$ & & \\
\hline CР250 & 0.02 & 0.70 & $0.12 \pm 0.009$ & & & 0.006 & 0.92 & $0.16 \pm 0.005$ & & \\
\hline $\mathrm{CP} 279^{\mathrm{b}}$ & 0.002 & & & 0.25 & $0.03 \pm 0.004$ & 0.004 & & & 0.21 & $0.057 \pm 0.005$ \\
\hline CР303 & 0.004 & 0.75 & $0.18 \pm 0.01$ & & & 0.19 & 0.58 & $0.55 \pm 0.06$ & & \\
\hline CP $331^{b}$ & 0.05 & 0.29 & $0.20 \pm 0.02$ & & & 0.009 & 0.46 & $0.28 \pm 0.02$ & & \\
\hline
\end{tabular}

a Observed rate constants, amplitudes $(\mathrm{A})$ and standard errors were determined from fits to $f_{\mathrm{N}}=\mathrm{A}_{1}\left(1-\mathrm{e}^{-1}\right)+f_{\mathrm{N}}(0)$ or $f_{\mathrm{N}}=\mathrm{A}_{1}\left(1-\mathrm{e}^{-\mathrm{k} 11}\right)+$ $\mathrm{A}_{2}\left(1-\mathrm{e}^{-\mathrm{k}_{2} 1}\right)+f_{\mathrm{N}}(0) \cdot f_{\mathrm{N}}(0)$ is the fraction of native RNA in the initial time (15-30 sec). Rate constants from two to three independent trials varied $\pm 5 \%$. Reactions were carried out at $37^{\circ} \mathrm{C}$ in $\mathrm{T} 7$ buffer containing $15 \mathrm{mM} \mathrm{MgCl}$. Incomplete folding is due to residual unfolded RNA after 2 $\mathrm{h}$ and hydrolysis of the cyclization junction in permuted RNAs.

${ }^{b}$ Extra $\mathrm{MgCl}_{2}$ was added to compensate for differences in the stabilities of CP RNAs. An additional $2 \mathrm{mM} \mathrm{MgCl}{ }_{2}$ was added to reactions of $\mathrm{CP} 194$ and CP148; CP331, extra $5 \mathrm{mM} \mathrm{MgCl} 2$ extra; CP279, an extra $13 \mathrm{mM} \mathrm{MgCl} 2$ extra.

${ }^{\mathrm{C}}$ Not applicable to circular (C-19) intron RNA.

nism of the ribozyme. This permutation introduces a nick adjacent to a non-native base pairing, alt $\mathrm{P} 3$, that competes against $\mathrm{P} 3$ and causes the $\mathrm{P} 3-\mathrm{P} 9$ domain of the ribozyme to misfold (Pan and Woodson 1998). A nick in J8/7 is expected to disfavor alt P3 relative to $\mathrm{P} 3$, and may also facilitate conversion of misfolded intermediates to the native structure (Heilman-Miller and Woodson 2003). In agreement with these predictions, previous studies demonstrated that a significant portion of CP303 RNA refolds faster than L-21 ribozyme in splicing buffer (Heilman-Miller and Woodson 2003).

Under transcription conditions, all of the CP303 folds slowly compared with the L-21 ribozyme $\left(k_{\text {obs }}=0.18\right.$ or $0.39 \mathrm{~min}^{-1}$; Tables 1,2$)$. The loss of the rapid burst of native CP303 RNA may be due to the lower concentration of monovalent ions in transcription buffer compared with splicing buffer (Heilman-Miller et al. 2001). Approximately $20 \%$ of the RNA folds correctly within the time required to load the RNA on the native gel, however, if CP303 is allowed to fold sequentially during transcription (Fig. 4C). In addition, the remaining RNA folds about twice as fast as $\left(k_{\text {obs }}=0.52 \mathrm{~min}^{-1}\right)$ as it does when refolded in transcription buffer $\left(k_{\mathrm{obs}}=0.18 \mathrm{~min}^{-1}\right)$. These observations suggest that cotranscriptional folding (or high salt) activate pathways that are not populated during refolding in T7 buffer. These bypass long-lived folding intermediates that otherwise limit the formation of native ribozyme.

\section{An alternative P3 pairing slows refolding of CP303}

Cotranscriptional folding may permit 20\% of CP303 RNA to rapidly form the native structure by increasing the prob-

TABLE 2. Comparison of refolding and sequential folding rates, E. coli RNA polymerase ${ }^{\mathrm{a}}$

\begin{tabular}{|c|c|c|c|c|c|c|c|c|}
\hline \multirow[b]{2}{*}{ RNA } & \multicolumn{3}{|c|}{ Refolding } & \multicolumn{5}{|c|}{ Sequential folding } \\
\hline & $f_{\mathrm{N}}(0)$ & $A_{1}$ & $k_{1}\left(\min ^{-1}\right)$ & $f_{\mathrm{N}}(0)$ & $A_{1}$ & $k_{1}\left(\min ^{-1}\right)$ & $\mathrm{A}_{2}$ & $k_{2}\left(\min ^{-1}\right)$ \\
\hline L-21 & 0.02 & 0.88 & $0.29 \pm 0.02$ & 0.02 & 0.78 & $0.65 \pm 0.08$ & & \\
\hline C-19 & 0.003 & 0.84 & $0.16 \pm 0.008$ & $N A^{c}$ & $N A^{c}$ & $N A^{c}$ & & \\
\hline CP91 ${ }^{\mathrm{b}}$ & 0.13 & 0.66 & $0.086 \pm 0.004$ & 0.03 & 0.26 & $1.5 \pm 0.45$ & 0.49 & $0.06 \pm 0.006$ \\
\hline $\mathrm{CP} 111^{\mathrm{b}}$ & 0.02 & 0.77 & $0.21 \pm 0.006$ & 0.06 & 0.61 & $0.16 \pm 0.01$ & & \\
\hline $\mathrm{CP} 148^{\mathrm{b}}$ & 0.18 & 0.52 & $0.03 \pm 0.002$ & 0.05 & 0.64 & $0.09 \pm 0.005$ & & \\
\hline $\mathrm{CP} 194^{\mathrm{b}}$ & 0.01 & 0.71 & $0.078 \pm 0.008$ & 0.05 & 0.68 & $0.15 \pm 0.01$ & & \\
\hline СР250 & 0.003 & 0.86 & $0.12 \pm 0.007$ & 0.04 & 0.54 & $0.127 \pm 0.009$ & & \\
\hline СР303 & 0.01 & 0.82 & $0.34 \pm 0.02$ & 0.09 & 0.16 & $0.38 \pm 0.02$ & 0.36 & $0.03 \pm 0.005$ \\
\hline
\end{tabular}

abserved rate constants and standard errors were determined as in Table 1. Rate constants from two to three independent trials varied $\pm 5 \%$. Reactions were carried out at $37^{\circ} \mathrm{C}$ in $E$. coli buffer containing $7 \mathrm{mM}$ magnesium acetate and $20 \mathrm{mM} \mathrm{NaCl}$ (see Materials and Methods).

${ }^{\mathrm{b}} \mathrm{An}$ extra $2 \mathrm{mM} \mathrm{MgCl}$, was added to stabilize these CP RNAs.

${ }^{\mathrm{c}}$ Not applicable. 
ability of forming the P3 helix. To test if P3 is formed more frequently during sequential folding of CP303, an oligonucleotide complementary to the 5 ' strand of P3 ("antiP3") was added to transcription reactions immediately after the addition of nucleotide triphosphates. Anti-P3 binds misfolded intermediates containing alt P3 (Pan and Woodson 1998), but does not bind the native ribozyme when the RNA is prefolded under T7 transcription conditions (data not shown).

Addition of anti-P3 after the start of transcription halved the overall rate of RNA folding and eliminated the initial burst of native RNA (Fig. 5A). This result indicates that the burst in the folding kinetics is sensitive to the equilibrium between P3 and alt P3 as expected (Pan and Woodson 1998). Antisense oligonucleotides complementary to other regions of the ribozyme do not have such a large effect on the fast folding phase of CP303 (data not shown).

Anti-P3 oligonucleotide also results in a twofold decrease in the observed rate of refolding of CP303, but no change in
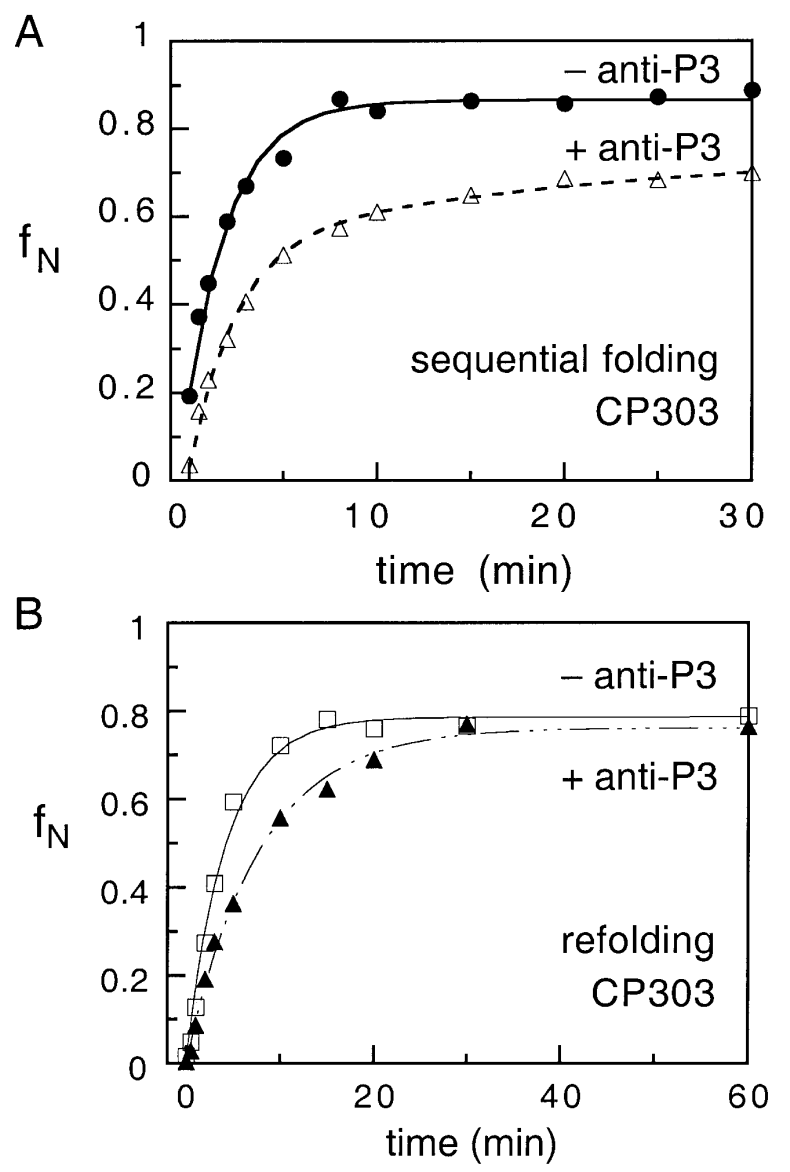

FIGURE 5. Formation of $\mathrm{P} 3$ during sequential folding of $\mathrm{CP} 303$ RNA. (A) Sequential folding (T7) in the presence or absence of anti-P3 oligonucleotide as in Materials and Methods. (-) anti-P3 (filled circles) $f_{\mathrm{N}}(0)=0.19, k_{\text {obs }}=0.41 \pm 0.03 \mathrm{~min}^{-1} ;(+)$ anti-P3 (open triangles) $f_{\mathrm{N}}(0)=0, k_{\mathrm{obs}}=0.25 \pm 0.02 \mathrm{~min}^{-1}$. (B) Refolding (T7). (-) anti-P3 (open squares) $k_{\mathrm{obs}}=0.23 \pm 0.02 \mathrm{~min}^{-1}$; (+) anti-P3 (filled triangles) $k_{\mathrm{obs}}=0.13 \pm 0.006 \mathrm{~min}^{-1}$. the final extent of refolding (Fig. 5B). The slower folding rate is consistent with the presence of alt P3 in many folding intermediates (Pan and Woodson 1998). That anti-P3 reduces the burst amplitude of sequential folding reactions but not the extent of refolding suggests that the order in which the ribozyme sequences are transcribed in CP303 increases the probability of forming the native P3 pseudoknot in early folding intermediates, resulting in a small population that rapidly reaches the native structure. Differences in the final extent of folding may reflect the greater accessibility of P3 to the antisense oligomer during transcription.

\section{Alternative base pairing in P9 slows refolding of CP303}

Non-native interactions beside alt P3 are also likely to inhibit refolding of CP303. Refolding of CP303 is slower than even the second phase of sequential folding $\left(0.18 \mathrm{~min}^{-1}\right.$ versus $0.55 \mathrm{~min}^{-1}$ ), and slower than refolding of the L-21 ribozyme $\left(k_{\mathrm{obs}}=0.31 \mathrm{~min}^{-1}\right)$. In support of this idea, denaturation of $\mathrm{CP} 303$ at $95^{\circ} \mathrm{C}$ in $2 \mathrm{M}$ urea prior to the addition of $\mathrm{Mg}^{2+}$ enabled all of the RNA to fold at a rate of $3 \mathrm{~min}^{-1}$, fivefold faster than controls in which urea is added to folding reactions containing $\mathrm{Mg}^{2+}$ at $37^{\circ} \mathrm{C}$ (HeilmanMiller 2001). In comparison, urea denaturation has only a small effect on refolding of the L-21 ribozyme (Emerick and Woodson 1993; Heilman-Miller 2001).

As cotranscriptional folding has a much greater effect on CP RNAs than the L-21 ribozyme, we looked for non-native interactions that selectively inhibit refolding of the permuted RNAs, but that may be avoided during cotranscriptional folding. A good candidate was an alternative secondary structure that replaces P9 with 12 base pairs spanning the cyclization junction between U20 and G414 (Fig. 6A). This pairing was predicted by the MFOLD computer algorithm (Mathews et al. 1999) for every CP RNA, but is not predicted to form in the L-21 Sca I ribozyme.

To examine the possibility that $\mathrm{P} 9$ misfolds, a ${ }^{32} \mathrm{P}$-labeled oligonucleotide (15 mer) that base pairs with the stem-loop of P9 was incubated with an excess of unlabeled L-21 and CP303 RNA. As shown in Figure 6B, the anti-P9 oligonucleotide binds the L-21 ribozyme, indicating that it competes with the native P9 helix. By contrast, little anti-P9 binds CP303 RNA even after a 30-min incubation, suggesting that the P9 target forms a very stable secondary structure that is refractory to competitive oligonucleotide binding.

Addition of excess anti-P9 increases the refolding rate of CP303 twofold (Fig. 6C). This may be due to destabilization of non-native intermediates by binding of the anti-P9 oligonucleotide, and is further evidence that mispairing of P9 contributes to the very slow refolding of CP303. Addition of anti-P9 does not affect the sequential folding rate of CP303 (Fig. 6D), indicating that rearrangement of sequentially 
A

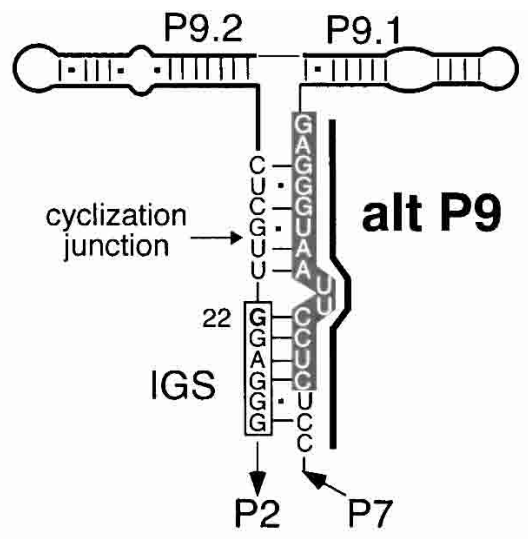

C

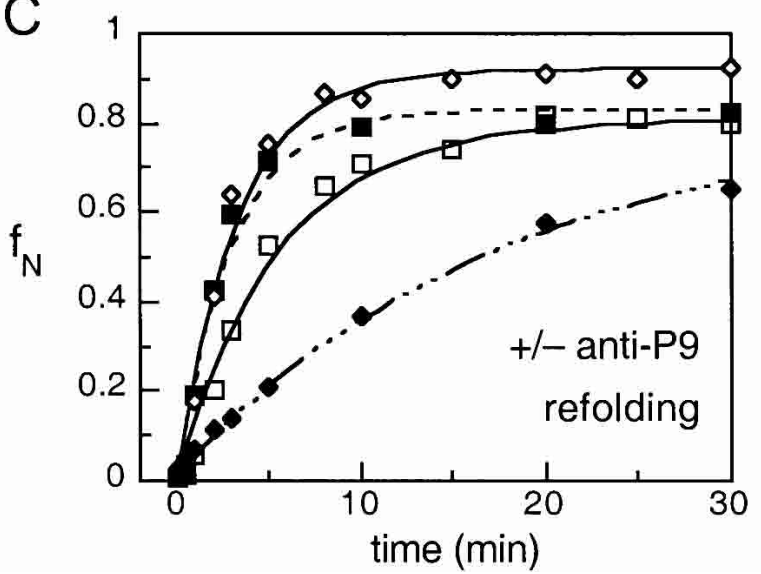

B refolding; ${ }^{32} \mathrm{P}$ anti-P9

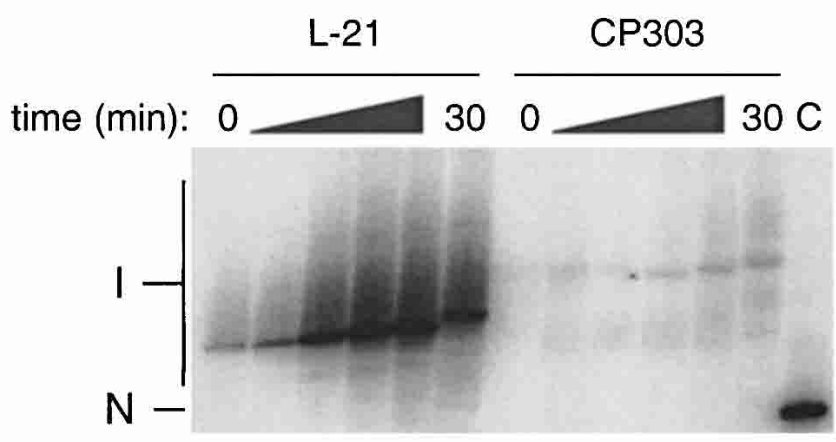

D

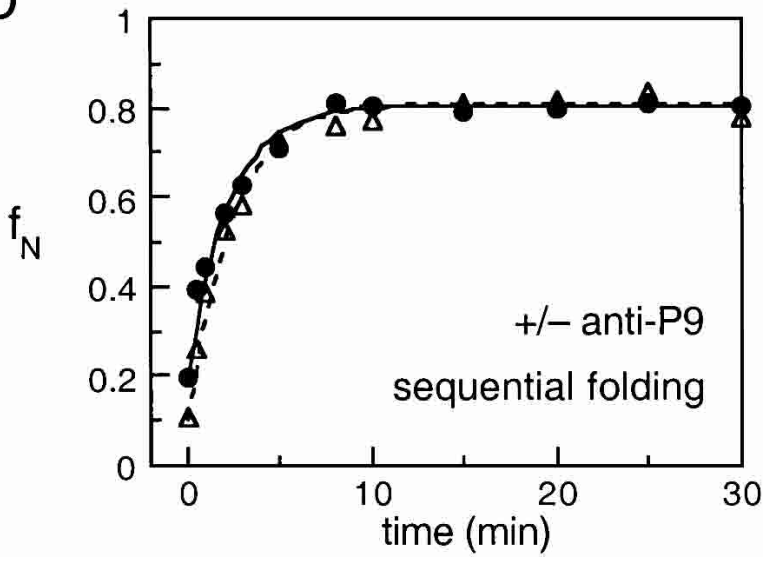

FIGURE 6. Folding of P9 during transcription of CP303. (A) Proposed alternative secondary structure (alt P9) created by joining the $5^{\prime}$ and $3^{\prime}$ ends of the ribozyme displaces native P9 (gray). Nucleotides that are complementary to anti-P9 15 mer are indicated by a thin line. (B) Gel shift assay for binding of anti-P9 oligonucleotide to ribozyme. Unlabeled L-21 or CP303 RNA $(1 \mu \mathrm{M})$ was incubated $0-$ to 30 min with $5^{\prime}\left[{ }^{32} \mathrm{P}\right]-\mathrm{labeled}$ oligonucleotide in T7 buffer (refolding conditions) before native PAGE. C, control containing prefolded ${ }^{32} \mathrm{P}$-labeled ribozyme. I, folding intermediates; N, native RNA. (C) Refolding reactions (T7) in the presence or absence of anti-P9. CP303 (-) anti-P9 (open squares) $0.18 \pm 0.02$ $\mathrm{min}^{-1}$; CP303 (+) anti-P9 (filled squares) $0.33 \pm 0.04 \mathrm{~min}^{-1}$; L-21 (-) anti-P9 (open diamonds) $0.30 \pm 0.02 \mathrm{~min}^{-1}$; L-21 (+) anti-P9 (filled diamonds) $0.05 \pm 0.002 \mathrm{~min}^{-1}$. (D) Sequential folding (T7). CP303 (-) anti-P9 (filled circles) $0.46 \pm 0.03 \mathrm{~min}^{-1}$; CP303 (+) anti-P9 (open diamonds) $0.43 \pm 0.03 \mathrm{~min}^{-1}$.

folded intermediates is not improved (or inhibited) by oligonucleotide binding. In contrast, anti-P9 inhibits refolding of the L-21 ribozyme (Fig. 6C).

\section{Temperature dependence of sequential RNA folding reactions}

The results above suggested that the sequential folding pathways for CP303 are not the same as the refolding pathways. To obtain more information about the free energy barriers to folding, the temperature dependence of cotranscriptional folding and refolding in T7 transcription buffer were compared. Temperature can alter the rate of folding and elongation. However, the rate of T7 transcription at $25^{\circ} \mathrm{C}$ is about a third of the rate at $37^{\circ} \mathrm{C}$ (Chamberlin and Ring 1973a,b). This is less than the average 10-fold difference between the elongation rates of T7 and E. coli RNA polymerases (Golomb and Chamberlin 1974; Chamberlin et al. 1979). As we have already shown that a 10 -fold variation in elongation rate causes little difference in folding of the ribozyme, the temperature dependence of sequential folding is mostly expected to reflect structural rearrangements in the RNA.

Refolding and sequential folding during T7 transcription were measured at different temperatures for the L-21 and CP303 RNAs (Fig. 7A). Differences between sequential and refolding experiments were greatest at lower temperatures, with sequential folding increasing both the rate and extent of folding. The amplitude of the fast folding phase of CP303, which is only seen during cotranscriptional folding, increased slightly with temperature $\left(A_{\text {fast }}=9 \%\right.$ at $25^{\circ} \mathrm{C}$; $\mathrm{A}_{\text {fast }}=20 \%$ at $37^{\circ} \mathrm{C}$; Fig. $7 \mathrm{~A}$ ).

The Arrhenius activation energy $\left(E_{a}\right)$ for refolding of CP303 was twice as large $\left(50 \mathrm{kcal} \mathrm{mole}^{-1}\right)$ as $E_{a}$ of sequential folding ( $24 \mathrm{kcal} \mathrm{mole}^{-1}$; Fig. 7B). In contrast, cotranscriptional and refolding of the L-21 ribozyme have a steeper 

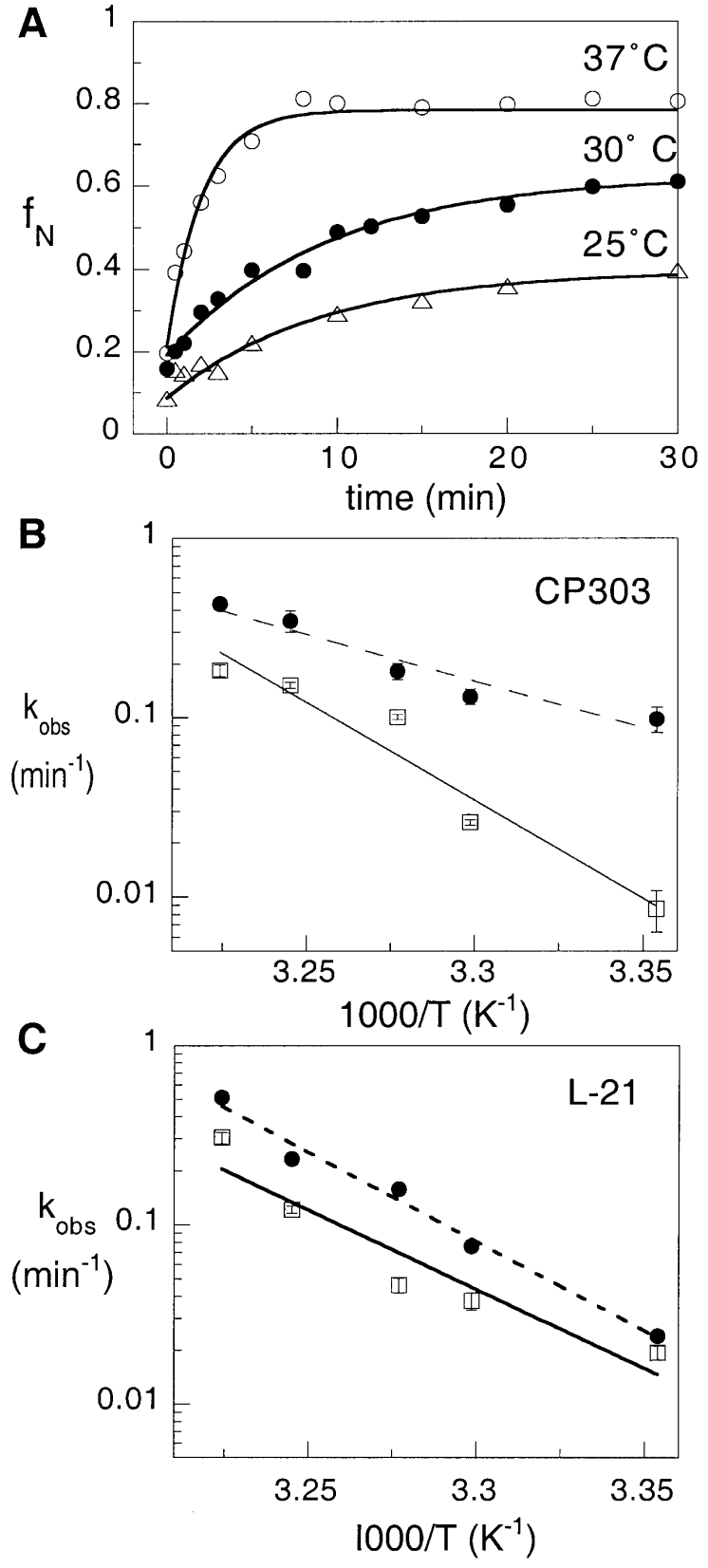

FIGURE 7. Temperature dependence of CP303 folding. (A) Sequential folding of CP303 following T7 transcription at 25,30 , and $37^{\circ} \mathrm{C}$. Progress curves were fit to a first-order rate equation. Decreased yields of native ribozyme at lower temperatures are due to kinetically trapped intermediates that do not fold at these temperatures. (B) Sequential folding of $\mathrm{CP}(303)$ results in a lower $E_{a}$. Arrhenius plot for folding of CP303. Refolding (open squares) $E_{a}=50.0 \mathrm{kcal} / \mathrm{mole}$; sequential folding (filled circles) $E_{a}=23.9 \mathrm{kcal} / \mathrm{mole}$. $(C) \mathrm{L}-21$ ribozyme. Refolding (open squares) $E_{a}=40.4 \mathrm{kcal} / \mathrm{mole}$; sequential folding (filled circles) $E_{a}=45.4 \mathrm{kcal} / \mathrm{mole}$.

temperature dependence (refolding, $-\mathrm{E}_{\mathrm{a}}=40 \mathrm{kcal} \mathrm{mole}^{-1}$; sequential folding, $45 \mathrm{kcal} \mathrm{mole}^{-1}$; Fig. 7C). These values are larger than $\Delta H \ddagger$ for refolding of L-21 ribozyme obtained previously (Rook et al. 1998), although this may reflect differences in the folding assay and experimental condi- tions. As the activation energy correlates with the thermal energy required to disrupt existing structures to reach the transition state, these results indicate that a less energetically costly rearrangement of $\mathrm{CP} 303$ is required following transcription than during refolding.

\section{DISCUSSION}

\section{Transcription and ribozyme folding}

Sequential formation of RNA interactions during transcription might be expected to simplify the folding problem by limiting the scope of the conformational search. Here, we find that cotranscriptional folding of the Tetrahymena ribozyme is only twice as fast overall as refolding. This is much less than the estimated rate of self-splicing in Tetrahymena $\left(t_{1 / 2} \sim 2 \mathrm{sec}\right)$ (Brehm and Cech 1983), and slower than the fast folding pathway of the ribozyme in vitro $\left(t_{1 / 2} \sim 0.7 \mathrm{sec}\right)$ (Pan et al. 2000; Zhuang et al. 2000). A slower elongation rate does not improve the formation of native ribozyme, because the folding rate was similar whether the RNA was transcribed by phage T7 or E. coli polymerase. These results are analogous to those obtained for RNase P RNA (Pan et al. 1999a, 1999b). Thus, sequential folding is not sufficient for these large ribozymes to fold at a physiologically reasonable speed in vitro.

By contrast, sequential folding increased the fraction of circularly permuted RNA that formed the native structure in the initial $10 \mathrm{~min}$. Thus, the accumulation of interactions during elongation of the RNA chain alters the distribution of folding intermediates, leading to a change in the overall folding kinetics. A change in folding pathway is supported by differences in the hybridization of antisense oligonucleotides directed against P3 and P9, and by hybridization of other oligonucleotides (Heilman-Miller 2001).

A surprising result of these studies is that transcription rarely reduced the rate of folding, among the variants of the Tetrahymena ribozyme examined. One exception is CP148, for which the amplitude of the early transition was higher after refolding. Because of the many possible folding pathways for RNA of this size, we expected that transcription might enhance nonproductive folding pathways as frequently as productive pathways. It is of interest to consider why this was not what we typically observed, and why the circularly permuted sequences, which do not occur in nature, are more dependent on cotranscriptional folding than the L-21 ribozyme.

\section{Sequence order and sequential folding of CP303}

The cartoon in Figure 8 suggests how transcription might populate a fast folding pathway for $\mathrm{CP} 303$, while making less difference to folding kinetics of the L-21 ribozyme. In the L-21 ribozyme, P3 is easily displaced by alt P3, which involves nucleotides that are much closer in sequence. Mis- 

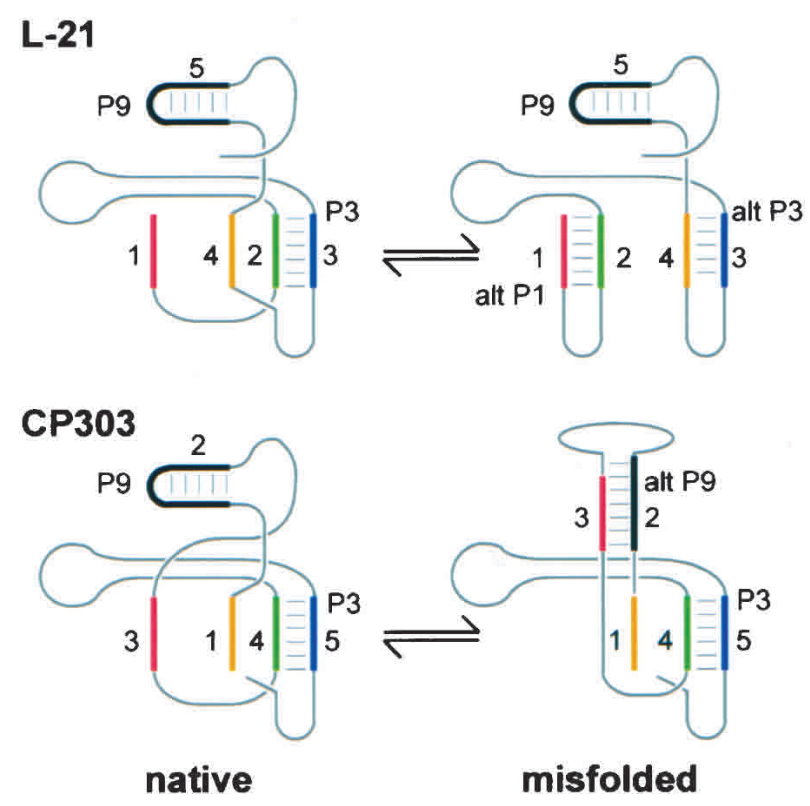

FIGURE 8. Model for alternative folding pathways. Sequential formation of base pairing interactions from the $5^{\prime}$ end of the L-21 ribozyme favors non-native structures containing alt P1 and alt P3. Sequential folding of CP303 permits P9 and the IGS to interact before the nucleotides that form P3 are transcribed. Sequential folding may favor the native $\mathrm{P} 9$ helix, while refolding of CP303 in transcription buffer favors alt P9.

pairing of $\mathrm{P} 3$ is also promoted by an upstream interaction between the internal guide sequence (IGS) and the $5^{\prime}$ strand of P3 (alt P1) (Pan and Woodson 1998). Hence, alt P1 or other improper pairings can trigger misfolding early during elongation of the L-21 ribozyme.

In CP303, the sequence distance between nucleotides that form alt P3 is large, improving the chance of forming P3 (Heilman-Miller and Woodson 2003). When transcription begins at G303, J8/7 and the P9 domain are synthesized before the IGS. Consequently, interactions with the P9 domain could tie up the IGS, pre-empting the formation of alt $\mathrm{P} 1$, and further improving the chance of forming P3 instead of alt P3. However, alt P9 is predicted to be very stable and itself resistant to rearrangement. Sequential folding of CP303 may favor the native $\mathrm{P} 9$ helix over alt $\mathrm{P} 9$, producing intermediates that temporarily engage the IGS in a weaker base pairing downstream of $\mathrm{P} 9$ ( $\mathrm{H}$. Isambert, unpubl.). The resulting intermediates (containing P3 and P9) could rearrange to the native structure more rapidly than those containing alt P9.

\section{Sequential folding favors branched secondary structures}

Sequential folding can favor the search for a unique native structure in two ways: by kinetically trapping the RNA in metastable intermediates of higher free energy than those formed during simultaneous refolding of the entire tran- script, and by favoring branched secondary structures with many stem-loops. The former would enable the intermediates to rearrange more easily to the native conformation, and may account for the lower activation energy for cotranscriptional folding of CP303. This may also explain why cotranscriptional folding is important for translational control in phage MS2 (Groeneveld et al. 1995; Poot et al. 1997), and reduces the cold sensitivity of $30 \mathrm{~S}$ ribosome assembly (Dammel and Noller 1993; Besancon and Wagner 1999). As we argue below, the latter may improve the formation of tertiary structure.

As the RNA emerges from the transcription elongation complex, stem-loops involving nearby nucleotides are entropically favored and more likely to form than base pairs between distant residues. Some of these stem-loops will be sufficiently stable to persist for several seconds, especially if reinforced by the folding pattern of downstream sequences. Consequently, the gradual accumulation of local interactions as the RNA is elongated is expected to produce more branched secondary structures than if the RNA were allowed to seek the thermodynamically most stable arrangement of base pairs in the absence of $\mathrm{Mg}^{2+}$. Because most ribozymes and stable RNAs are formed from branched secondary structures, the intermediates produced during transcription are more likely to match the native conformation than the rod-like conformations that are often obtained when RNAs are equilibrated in low ionic strength buffer (Cole et al. 1972).

For example, self-cleavage of the hepatitis delta virus (HDV) ribozyme is inhibited by interactions with downstream sequences, which base pair with the ribozyme sequences in a rod-like structure (Lazinski and Taylor 1995). The extent of self-cleavage in vitro during transcription depends on the length of the downstream sequence and the rate of transcription elongation (Diegelman-Parente and Bevilacqua 2002).

In the Tetrahymena ribozyme, the order of RNA synthesis appears to create a window of opportunity in which native contacts (P3 and P9) out-compete non-native interactions (alt $\mathrm{P} 1$, alt $\mathrm{P} 3$, and alt $\mathrm{P} 9$ ), leading more rapidly to the native tertiary structure. Because this competition depends on the sequence of the RNA, as well as the order in which that sequence is transcribed, the details of sequential folding pathways are complex. Nonetheless, the results obtained here and in other systems suggest ways in which the formation of RNA structure can be productively coupled to transcription.

\section{MATERIALS AND METHODS}

\section{RNA preparation}

Uniformly $\left[{ }^{32} \mathrm{P}\right]$-labeled L-21Sca ribozyme was transcribed with T7 RNA polymerase from pT7L-21 DNA digested with Sca I as previously described (Zaug et al. 1988). A template for E. coli RNA 
polymerase was created by PCR amplification with an upstream primer containing the trc promoter. Templates for circularly permuted (CP) RNAs were prepared by PCR amplification of the tandem intron template pT7L-21L-19, as previously described (Heilman-Miller and Woodson 2003). The intron was cyclized by joining the natural $3^{\prime}$ end (G414) to U20 near the $5^{\prime}$ end. New 5' and $3^{\prime}$ ends were created by placing a T7 or E. coli trc promoter upstream of the desired transcription start site. Promoter sequences of the T7 promoter or E. coli trc promoter were included in the upstream PCR primer.

Transcription reactions of CP RNAs were incubated $30 \mathrm{~min}$ at $30^{\circ} \mathrm{C}$ to reduce the extent of hydrolysis. All transcription mixtures were passed over a TE-100 spin column (Clontech), and the RNA stored in $10 \mathrm{mM}$ Tris- $\mathrm{HCl} \mathrm{pH}$ 7.5, $1 \mathrm{mM}$ EDTA (TE) before use in refolding reactions (Emerick and Woodson 1993). Control reactions with 2' O-methyl templates (Sherlin et al. 2001) suggest that the addition of nontemplated nucleotides to the $3^{\prime}$ end of a percentage of transcripts does not significantly affect the results of these folding assays (Heilman-Miller and Woodson 2003).

\section{Sequential folding during T7 transcription}

Template DNA $(1 \mu \mathrm{g})$ was combined with $20 \mu \mathrm{Ci}[\alpha]-{ }^{32} \mathrm{P}-\mathrm{GTP}$ (3000 Ci/mmole, NEN) and $1 \mu \mathrm{L}(200-500 \mathrm{U})$ T7 RNA polymerase in T7 transcription buffer ( $40 \mathrm{mM}$ Tris- $\mathrm{HCl} \mathrm{pH} 7.5,15 \mathrm{mM}$ $\mathrm{MgCl}_{2}, 5 \mathrm{mM} \mathrm{DTT}$, and $2 \mathrm{mM}$ spermidine) (Davanloo et al. 1984). This mixture was incubated $2 \mathrm{~min}$ at $37^{\circ} \mathrm{C}$. A $10 \times$ cocktail of nucleotide triphosphates (final concentrations $0.5 \mathrm{mM}$ ATP, 0.5 mM CTP, $0.5 \mathrm{mM}$ UTP, $0.125 \mathrm{mM} \mathrm{GTP}, 10 \mathrm{mg} / \mathrm{mL}$ heparin) was added to begin transcription, bringing the reaction volume to 40 $\mu \mathrm{L}$. Where noted (see Table 1), additional $\mathrm{MgCl}_{2}$ was added after the NTP cocktail. A $2-\mu \mathrm{L}$ aliquot was removed immediately after the addition of nucleotide triphosphates and heparin (time " 0 " $\approx 5-10 \mathrm{sec}$ ). The temperature was $37^{\circ} \mathrm{C}$ except where indicated otherwise.

At various times $(0-2 \mathrm{~h})$, aliquots were removed, mixed with loading dyes ( $10 \%$ glycerol, $0.1 \%$ xylene cyanol final) and loaded immediately on a native $8 \%$ polyacrylamide gel containing $3 \mathrm{mM}$ $\mathrm{MgCl}_{2}$ in the running buffer as previously described (Emerick and Woodson 1994). Gels were run continuously throughout experiment $\left(4-10^{\circ} \mathrm{C}\right)$, with wattage continually adjusted to ensure that samples entered the gel matrix within 15-30 s of loading. Previous work indicates that folding is arrested after the RNA enters the gel (Emerick and Woodson 1994). Gels were run an additional $4 \mathrm{~h}$ at $15 \mathrm{~W}$ after the final sample was loaded. The fraction native RNA $\left(f_{\mathrm{N}}\right)$ at each time was normalized to the counts for full-length ribozyme in each lane and fit to first-order or double exponential rate equations as described previously (Heilman-Miller et al. 2001).

\section{Sequential folding during $E$. coli RNA polymerase transcription}

Template DNA $(\sim 2 \mathrm{nM}$, final) was combined in a $25-\mu \mathrm{L}$ volume with $20 \mu \mathrm{Ci}[\alpha]-{ }^{32} \mathrm{P}-\mathrm{GTP}(3000 \mathrm{Ci} / \mathrm{mmole}, \mathrm{NEN})$ and $3 \mathrm{U}$ E. coli RNA polymerase holoenzyme (Epicentre Technologies) in E. coli transcription buffer (50 mM Tris- $\mathrm{HCl} \mathrm{pH} 7.8,20 \mathrm{mM} \mathrm{NaCl}, 3$ mM magnesium acetate, $0.1 \mathrm{mM}$ EDTA, $0.1 \mathrm{mM}$ DTT, $250 \mu \mathrm{g} / \mathrm{mL}$ BSA) (Jair et al. 1996). The reaction mixture was incubated $15 \mathrm{~min}$ at $37^{\circ} \mathrm{C}$ to prepare the open complex, then combined with a mixture of nucleotide triphosphates $(0.96 \mathrm{mM}$ each ATP, UTP, CTP, $0.3 \mathrm{mM}$ GTP), $1.2 \mathrm{mg} / \mathrm{mL}$ heparin, and an additional 2-6 mM $\mathrm{MgCl}_{2}$ (see Table 2) in E. coli transcription buffer, to a final volume of $40 \mu \mathrm{L}$. Samples were analyzed by native PAGE as described above.

\section{RNA refolding}

Refolding experiments were conducted under the same conditions used for either T7 or E. coli RNA polymerase transcription, except DNA and polymerase were omitted. Refolding was initiated by addition of uniformly ${ }^{32} \mathrm{P}$-labeled full-length RNA to a prepared transcription cocktail at $37^{\circ} \mathrm{C}$ or other temperatures where indicated. At various times $(0-2 \mathrm{~h})$, aliquots were removed, mixed with loading dyes, and loaded immediately onto a native $8 \%$ gel, as described above. The fraction native RNA $\left(f_{\mathrm{N}}\right)$ at each time was analyzed as before (Heilman-Miller and Woodson 2003).

\section{Urea denaturation experiments}

Uniformly ${ }^{32} \mathrm{P}$-labeled RNA in TE was heated $2 \mathrm{~min}$ at $95^{\circ} \mathrm{C}$ in the presence or absence of $4 \mathrm{M}$ urea. Following heat treatment, the RNA or RNA + urea mixture was diluted twofold with deionized (18 $\mathrm{M} \Omega$ ) water on ice. Refolding reactions were carried out as described previously in a T7 transcription cocktail. The final urea concentration was $0.2 \mathrm{M}$. Alternatively, refolding reactions were carried out as previously described, except $0.2 \mathrm{M}$ urea was added to the reaction mixture.

\section{Antisense oligonucleotide competition}

Where stated, $50 \mu \mathrm{M}$ antisense oligonucleotide was added to sequential folding or refolding experiments. For sequential folding experiments, the antisense oligonucleotide was added immediately after addition of nucleotide triphosphates and heparin. Oligonucleotide binding experiments (gel shift) were conducted in T7 buffer with nucleotide triphosphates and heparin, with $1 \mu \mathrm{M}$ (final) unlabeled L-21 ribozyme or circularly permuted RNA and trace amounts of $5^{\prime}{ }^{32} \mathrm{P}$-labeled antisense oligonucleotide $\left(\sim 10^{6}\right.$ $\mathrm{cpm})$ at $37^{\circ} \mathrm{C}$. Reactions were initiated by the addition of ribozyme RNA. Aliquots were removed at various times and loaded directly onto a native $8 \%$ gel. Bound oligonucleotide was detected by autoradiography of dried gels.

\section{Primers and antisense oligonucleotides}

Anti-P3, 5'-ATTTGACGGTCTTGC; anti-P9, 5' -CCCATTAAGG AGAGG. Sequences of PCR primers used in this study are available from the authors on request.

\section{ACKNOWLEDGMENTS}

The authors thank Jie Pan for her early work to develop cotranscriptional folding assays, Hervé Isambert for the communication of unpublished data and helpful discussions, Richard Wolf for helpful advice, and Yong Cao for the preparation of T7 RNA 
polymerase. This work was supported by a grant from the NIH (GM60819).

The publication costs of this article were defrayed in part by payment of page charges. This article must therefore be hereby marked "advertisement" in accordance with 18 USC section 1734 solely to indicate this fact.

Received February 3, 2003; accepted March 11, 2003.

\section{REFERENCES}

Ansari, A., Kuznetsov, S.V., and Shen, Y. 2001. Configurational diffusion down a folding funnel describes the dynamics of DNA hairpins. Proc. Natl. Acad. Sci. 98: 7771-7776.

Balzer, M. and Wagner, R. 1998. Mutations in the leader region of ribosomal RNA operons cause structurally defective $30 \mathrm{~S}$ ribosomes as revealed by in vivo structural probing. J. Mol. Biol. 276: $547-557$.

Besancon, W. and Wagner, R. 1999. Characterization of transient RNA-RNA interactions important for the facilitated structure formation of bacterial ribosomal 16S RNA. Nucleic Acids Res. 27: 4353-4362.

Boyle, J., Robillard, G.T., and Kim, S.H. 1980. Sequential folding of transfer RNA. A nuclear magnetic resonance study of successively longer tRNA fragments with a common $5^{\prime}$ end. J. Mol. Biol. 139: 601-625.

Brehm, S.L. and Cech, T.R. 1983. Fate of an intervening sequence ribonucleic acid: Excision and cyclization of the Tetrahymena ribosomal ribonucleic acid intervening sequence in vivo. Biochemistry 22: 2390-2397.

Chamberlin, M. and Ring, J. 1973a. Characterization of T7-specific ribonucleic acid polymerase. 1 . General properties of the enzymatic reaction and the template specificity of the enzyme. J. Biol. Chem. 248: $2235-2244$.

. 1973b. Characterization of T7-specific ribonucleic acid polymerase. II. Inhibitors of the enzyme and their application to the study of the enzymatic reaction. J. Biol. Chem. 248: 2245-2250.

Chamberlin, M.J., Nierman, W.C., Wiggs, J., and Neff, N. 1979. A quantitative assay for bacterial RNA polymerases. J. Biol. Chem. 254: 10061-10069.

Chao, M.Y., Kan, M.C., and Lin-Chao, S. 1995. RNAII transcribed by IPTG-induced T7 RNA polymerase is non-functional as a replication primer for ColE1-type plasmids in Escherichia coli. Nucleic Acids Res. 23: 1691-1695.

Cole, P.E. and Crothers, D.M. 1972. Conformational changes of transfer ribonucleic acid. Relaxation kinetics of the early melting transition of methionine transfer ribonucleic acid (Escherichia coli). Biochemistry 11: 4368-4374.

Cole, P.E., Yang, S.K., and Crothers, D.M. 1972. Conformational changes of transfer ribonucleic acid. Equilibrium phase diagrams. Biochemistry 11: 4358-4368.

Dammel, C.S. and Noller, H.F. 1993. A cold-sensitive mutation in $16 \mathrm{~S}$ rRNA provides evidence for helical switching in ribosome assembly. Genes Dev. 7: 660-670.

Daube, S.S. and von Hippel, PH. 1994. RNA displacement pathways during transcription from synthetic RNA-DNA bubble duplexes. Biochemistry 33: 340-347.

Davanloo, P., Rosenberg, A.H., Dunn, J.J., and Studier, FW. 1984. Cloning and expression of the gene for bacteriophage T7 RNA polymerase. Proc. Natl. Acad. Sci. 81: 2035-2039.

Diegelman-Parente, A. and Bevilacqua, P.C. 2002. A mechanistic framework for co-transcriptional folding of the HDV genomic ribozyme in the presence of downstream sequence. J. Mol. Biol. 324: $1-16$.

Emerick, V.L. and Woodson, S.A. 1993. Self-splicing of the Tetrahy- mena pre-rRNA is decreased by misfolding during transcription. Biochemistry 32: 14062-14067.

- 1994. Fingerprinting the folding of a group I precursor RNA. Proc. Natl. Acad. Sci. 91: 9675-9679.

Golomb, M. and Chamberlin, M. 1974. Characterization of T7-specific ribonucleic acid polymerase. IV. Resolution of the major in vitro transcripts by gel electrophoresis. J. Biol. Chem. 249: 2855-2863.

Groeneveld, H., Thimon, K., and van Duin, J. 1995. Translational control of maturation-protein synthesis in phage MS2: A role for the kinetics of RNA folding? RNA 1: 79-88.

Heilman-Miller, S.L. 2001. "Effect of counterion condensation, circular permutation, and transcription on folding of the Tetrahymena ribozyme.” Ph.D. thesis. Chemistry, University of Maryland, College Park.

Heilman-Miller, S.L. and Woodson, S.A. 2003. Perturbed folding kinetics of circularly permuted RNAs with altered topology. J. Mol. Biol. (in press).

Heilman-Miller, S.L., Pan, J., Thirumalai, D., and Woodson, S.A. 2001. Counterion condensation in folding of the Tetrahymena ribozyme. II. Counterion dependence of folding kinetics. J. Mol. Biol. 309: 57-68.

Jair, K.W., Fawcett, W.P., Fujita, N., Ishihama, A., and Wolf Jr., R.E. 1996. Ambidextrous transcriptional activation by SoxS: Requirement for the C-terminal domain of the RNA polymerase $\alpha$ subunit in a subset of Escherichia coli superoxide-inducible genes. Mol. Microbiol. 19: 307-317.

Kramer, F.R. and Mills, D.R. 1981. Secondary structure formation during RNA synthesis. Nucleic Acids Res. 9: 5109-5124.

Lazinski, D.W. and Taylor, J.M. 1995. Intracellular cleavage and ligation of hepatitis $\delta$ virus genomic RNA: Regulation of ribozyme activity by cis-acting sequences and host factors. J. Virol. 69: 1190-1200.

LeCuyer, K.A. and Crothers, D.M. 1994. Kinetics of an RNA conformational switch. Proc. Natl. Acad. Sci. 91: 3373-3377.

Lewicki, B.T., Margus, T., Remme, J., and Nierhaus, K.H. 1993. Coupling of rRNA transcription and ribosomal assembly in vivo. Formation of active ribosomal subunits in Escherichia coli requires transcription of rRNA genes by host RNA polymerase which cannot be replaced by bacteriophage T7 RNA polymerase. J. Mol. Biol. 231: 581-593.

Mathews, D.H., Sabina, J., Zuker, M., and Turner, D.H. 1999. Expanded sequence dependence of thermodynamic parameters improves prediction of RNA secondary structure. J. Mol. Biol. 288: 911-940.

Nagel, J.H., Gultyaev, A.P., Gerdes, K., and Pleij, C.W. 1999. Metastable structures and refolding kinetics in hok mRNA of plasmid R1. RNA 5: 1408-1418.

Pan, J. and Woodson, S.A. 1998. Folding intermediates of a selfsplicing RNA: Mispairing of the catalytic core. J. Mol. Biol. 280: 597-609.

Pan, J., Thirumalai, D., and Woodson, S.A. 1997. Folding of RNA involves parallel pathways. J. Mol. Biol. 273: 7-13.

Pan, T., Artsimovitch, I., Fang, X.W., Landick, R., and Sosnick, T.R. 1999a. Folding of a large ribozyme during transcription and the effect of the elongation factor NusA. Proc. Natl. Acad. Sci. 96: 9545-9550.

Pan, T., Fang, X., and Sosnick, T. 1999b. Pathway modulation, circular permutation and rapid RNA folding under kinetic control. J. Mol. Biol. 286: 721-731.

Pan, J., Deras, M.L., and Woodson, S.A. 2000. Fast folding of a ribozyme by stabilizing core interactions: Evidence for multiple folding pathways in RNA. J. Mol. Biol. 296: 133-144.

Poot, R.A., Tsareva, N.V., Boni, I.V., and van Duin, J. 1997. RNA folding kinetics regulates translation of phage MS2 maturation gene. Proc. Natl. Acad. Sci. 94: 10110-10115.

Repsilber, D., Wiese, S., Rachen, M., Schroder, A.W., Riesner, D., and Steger, G. 1999. Formation of metastable RNA structures by sequential folding during transcription: Time-resolved structural analysis of potato spindle tuber viroid (-)-stranded RNA by temperature-gradient gel electrophoresis. RNA 5: 574-584. 
Rook, M.S., Treiber, D.K., and Williamson, J.R. 1998. Fast folding mutants of the Tetrahymena group I ribozyme reveal a rugged folding energy landscape. J. Mol. Biol. 281: 609-620.

Sherlin, L.D., Bullock, T.L., Nissan, T.A., Perona, J.J., Lariviere, F.J., Uhlenbeck, O.C., and Scaringe, S.A. 2001. Chemical and enzymatic synthesis of tRNAs for high-throughput crystallization. RNA 7: 1671-1678.

Wallace, M.I., Ying, L., Balasubramanian, S., and Klenerman, D. 2001. Non-Arrhenius kinetics for the loop closure of a DNA hairpin. Proc. Natl. Acad. Sci. 98: 5584-5589.

Wang, M.D., Schnitzer, M.J., Yin, H., Landick, R., Gelles, J., and Block, S.M. 1998. Force and velocity measured for single molecules of RNA polymerase. Science 282: 902-907.

Woodson, S.A. 2000. Recent insights on RNA folding mechanisms from catalytic RNA. Cell. Mol. Life Sci. 57: 796-808.

Zarrinkar, P.P. and Williamson, J.R. 1994. Kinetic intermediates in RNA folding. Science 265: 918-924.

Zaug, A.J., Grosshans, C.A., and Cech, T.R. 1988. Sequence-specific endoribonuclease activity of the Tetrahymena ribozyme: Enhanced cleavage of certain oligonucleotide substrates that form mismatched ribozyme-substrate complexes. Biochemistry 27: 89248931.

Zhang, F., Ramsay, E.S., and Woodson, S.A. 1995. In vivo facilitation of Tetrahymena group I intron splicing in Escherichia coli preribosomal RNA. RNA 1: 284-292.

Zhuang, X., Bartley, L.E., Babcock, H.P., Russell, R., Ha, T., Herschlag, D., and Chu, S. 2000. A single-molecule study of RNA catalysis and folding. Science 288: 2048-2051. 

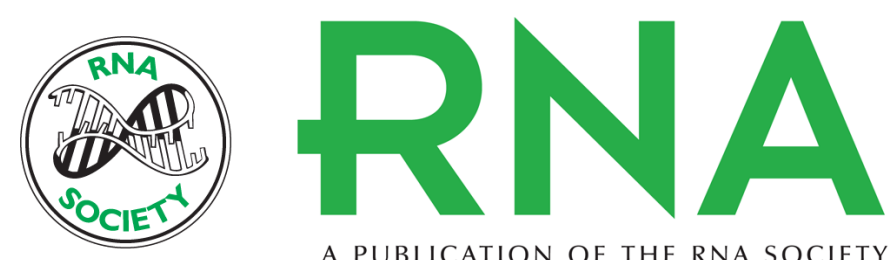

A PUBLICATION OF THE RNA SOCIETY

\title{
Effect of transcription on folding of the Tetrahymena ribozyme
}

\author{
SUSAN L. HEILMAN-MILLER and SARAH A. WOODSON
}

RNA 2003 9: 722-733

References This article cites 43 articles, 20 of which can be accessed free at:

http://rnajournal.cshlp.org/content/9/6/722.full.html\#ref-list-1

\section{License}

Email Alerting Receive free email alerts when new articles cite this article - sign up in the box at the Service top right corner of the article or click here.

To subscribe to $R N A$ go to:

http://rnajournal.cshlp.org/subscriptions 